\title{
Problematika Lembaga Pemasyarakatan dalam Sistem Peradilan Terpadu
}

\author{
Rugun Romaida Hutabarat \\ Fakultas Hukum Universitas Tarumanagara \\ Jalan Letjen S Parman, No. 1, Gogol, Jakarta Barat, 11440 \\ Email : rugunhutabarat@ymail.com
}

\begin{abstract}
Correctional criminal justice system be seen from the issue of crime system, the idea of coaching, over capacity, and the adverse effects of imprisonment. The new alternative of imprisonment to be important. This study uses normative. This paper will discuss the implementation of associated ideas correctional imprisonment in Indonesia current legislation and the future alternative accordance with the idea of humanity. The answer above problems: first, over capacity in prisons into correctional implications have not been the implementation of selective and limited idea. Second, in the future should give consideration criteria such as medical, family, professional or social considerations that force/urgent. Considering there are still many problems in the implementation of imprisonment, over capacity, not the realization of the idea of correctional, adverse effects of imprisonment and global criticisms, then alternative imprisonment integrating the idea of humanity, saving, rehabilitation and selective expected to realize the integrated criminal justice system.
\end{abstract}

Keywords: policy, correctional ide, integrated criminal justice system

\section{PENDAHULUAN}

Sanksi pidana penjara (imprisonment) dikenal sejak abad ke-15 sampai saat ini. Pidana penjara merupakan bentuk pidana untuk menggantikan pidana badan yang dilakukan pada jaman pra klasik yang dianggap kurang manusiawi. Pergantian tersebut kemudian dibarengi dengan perubahan dan perbaikan kondisi bangunan untuk menahan pelanggar hukum yang kemudian dikenal pidana sebagai bangunan penjara. ${ }^{1}$ Indonesia termasuk negara yang tetap mempertahankan pidana penjara. Dari seluruh ketentuan KUHP Indonesia, yang memuat perumusan delik kejahatan, yaitu sejumlah 587 pidana penjara tercantum di dalam 575 perumusan delik (kurang lebih 97,96\%), baik dirumuskan secara tunggal maupun dirumuskan secara alternatif dengan jenis-jenis pidana lainnya.

Pidana perampasan kemerdekaan (penjara dan kurungan) menjadi sangat primadona dalam penetapan dan penjatuhan pidana dalam kaitannya dengan tujuan pemidanaan, terutama pencapaiaan efek jera bagi pelaku dan pencapaian pencegahan umum. Padahal perkembangan konsepsi baru dalam hukum pidana, yang menonjol adalah perkembangan mengenai sanksi alternatif (alternatif sanction), dari pidana hilang kemerdekaan menjadi pidana denda, terutama terhadap tindak pidana yang diancam dengan pidana penjara di bawah satu tahun. Munculnya alternatif pidana penjara adalah wujud dari kritik-kritik terhadap efek buruk pidana penjara baik kritik dari sudut "strafmodus", kritik dari sudut "strafmaat" dan dari sudut "strafsoort".

Dalam prakteknya terlihat bahwa kritik demikian menjadi hal yang mudah ditemui di Indonesia. Menurut laporan situs antaranews.com 11 April 2016, Kementerian Hukum dan HAM membutuhkan dana untuk pembuatan lapas baru dengan kapasitas 1.000 orang, butuh Rp150 miliar dan diperlukan 200 orang (petugas). Sedangkan jumlah napi di seluruh lapas dan rutan di Indonesia mencapai 160.722 orang, jumlah tersebut meningkat menjadi lebih dari 180 ribu orang pada April 2016. Kekuatan anggaran yang ada sekarang tidak bisa dan tidak cukup membangun

\footnotetext{
${ }^{1}$ Menurut Sudarto pada Buku Kapita Selekta Hukum Pidana, (Bandung: Alumni, 1981), istilah bangunan penjara berbeda-beda dari negara yang satu ke negara yang lain, seperti di Inggris dikenal sebagai "bridewell", sedangkan di Belanda didirikan "rumah penertib" (tuchtuis) yang diperuntukkan untuk terpidana laki-laki dan "spinhuis" untuk terpidana wanita.
} 
lapas untuk menampung narapidana" (Menhumkam beberkan, 2016). Selain masalah over kapasitas lapas di Indonesia, perlu dipertimbangkan kembali keadaan ekonomi/sosial narapidana, terutama bagi penjatuhan pidana pendek atau sanksi penjara yang tidak lebih dari 1 (satu) tahun penjara.

Upaya mencari alternatif pidana penjara merupakan perwujudan dari kebijakan selektif dan limitatif dalam menggunakan pidana penjara. Barda Nawawi Arief menyatakan bahwa kebijakan selektif dan limitatif bukan bertujuan menghapuskan pidana penjara secara total, namun sekedar upaya menghindari sisi negatif dan kelemahan/kekurangan dari pidana penjara (Sudarto 1981). Dalam hal ini perlu dikembangkan alternatif pidana penjara dengan pertimbangan khusus terhadap pelaksanaan pidana penjara. Pertimbangan-pertimbangan demikian dapat dilihat dari beberapa aspek yaitu jumlah narapidana yang semakin meningkat, pertimbangan latar belakang ekonomi-sosial yang lemah dan pengurangan over kapasitas dengan membangun penjara baru atau mengurangi jumlah penghuninya. Praktek menunjukkan, upaya melalui pembangunan penjara-penjara baru tidak merupakan solusi yang berkelanjutan. Bahkan sejumlah Negara Eropa yang telah menaikkan/ memperluas program pembangunan penjara, jumlah napi mereka meningkat seiring dengan meningkatnya kapasitas penjara. Tambahan pula membangun penjara baru dan memeliharanya sangatlah mahal dengan menekan sumbersumber lainnya. Sementara itu beberapa instrument internasional merekomendasikan rasionalisasi kebijakan pemidanaan, termasuk penggunaan "alternative to prison" dengan berusaha mengurangi jumlah napi yang dikenakan pidana penjara dalam waktu lama (Sudarto 1981).

Berdasarkan pertimbangan atau alasan-alasan demikian maka pidana penjara menjadi persoalan penting terkait pelaksanaan pidana penjara dalam mewujudkan sistem peradilan pidana, sehingga tidak hanya menghukum tetapi melihat dari sisi hak asasi nara pidana ketika terjadi masalah over kapasitas yang bisa menghambat tujuan dari pelaksanaan pidana. Hal ini juga menjadi penetralisir efek buruk dan penuhnya lembaga pemasyarakatan di Indonesia, sehingga terwujud keseimbangan antara kepentingan perlindungan masyarakat dan kepentingan perlindungan individu. Melalui uraian latar belakang, perlu dirumuskan suatu permasalahan secara sistematis dalam bentuk pertanyaan, sehingga memberikan gambaran yang jelas dan memudahkan pemahaman akan masalah yang diteliti.

Berdasarkan hal tersebut, maka selanjutnya dibahas dalam tulisan ini mengenai bagaimana problematika lembaga pemasyarakatan dalam sistem peradilan pidana terpadu dan bagaimana kebijakan ide pemasyarakatan dalam sistem peradilan pidana terpadu di masa mendatang.

\section{METODE PENELITIAN}

Metode yang digunakan adalah yuridis normatif yaitu penelitian kepustakaan (Librarian Research), berupa penelitian terhadap data. Sedangkan data primer dalam penelitian ini hanya sebagai data penunjang (Rony, 1984). Penelitian ini juga menggunakan beberapa pendekatan yaitu pendekatan perundang-undangan (statute approach) dilakukan dengan menelaah semua undang-undang dan regulasi yang bersangkut paut dengan isu hukum yang ditangani (Peter 2010). Isu hukum yang ditangani dalam penelitian ini adalah pengenaan pidana penjara sistem pelaksanaan hukum pidana di Indonesia dan efek buruk dari pidana penjara itu sendiri. Pendekatan yang digunakan adalah pendekatan yuridis normatif yaitu dengan mengkaji atau menganalisis data sekunder yang terdiri dari berbagai literatur maupun jurnal yang membahas kebijakan hukum pidana terutama ide pelaksanaan pidana penjara. Hasil penelitian ini bersifat deskriptif analitis dan preskriptif. Deskriptif analitis yaitu suatu penelitian yang dilakukan secara 
deskriptif, terbatas pada usaha mengungkapkan suatu masalah dan keadaan sebagaimana adanya, sehingga hanya bersifat mengungkap atau memaparkan suatu peristiwa maupun fakta yang ada secara rinci, sistematis, dan menyeluruh sedangkan preskriptif merupakan pemecahan atas isu hukum yang diajukan dan secara etimologi berarti apa yang seharusnya(Titon, 2013).

\section{HASIL DAN PEMBAHASAN}

\section{A. Kebijakan Hukum Ide Pemasyarakatan dalam Sistem Peradilan Pidana Terpadu}

Putusan pengadilan yang berkekuatan hukum tetap dalam perkara pidana hanya dapat terjadi setelah seorang tersangka diproses menurut hukum acara pidana yang berlaku berdasarkan buktibukti yang kuat. Ketentuan mengenai hukum acara tersebut diatur dalam Undang-undang Nomor 8 Tahun 1981 tentang hukum acara pidana atau yang lebih dikenal dengan sebutan Kitab Undang undang Hukum Acara Pidana (KUHAP). Undang-undang tersebut mengatur proses penyelidikan, penyidikan, penuntutan, pemeriksaan di pengadilan, dan pelaksanaan pidana yang terangkum dalam sebuah sistem peradilan pidana terpadu (integrated criminal justice system). Dalam kerangka sistem peradilan pidana terpadu tersebut setidaknya terdapat empat lembaga yang bertanggungjawab dalam penegakan hukum yaitu Kepolisian, Kejaksaan, Pengadilan, dan Lembaga Pemasyarakatan (Lapas).

Dalam hal ini lembaga pemasyarakatan (lapas) sebagai salah satu institusi penegakan hukum merupakan muara dari peradilan pidana, yaitu sebagai pelaksana putusan yang dijatukan kepada para terpidana. Pelaksanaan pidana penjara bagi narapidana tidak dilakukan semata sebagai sebuah upaya balas dendam dan menjauhkan narapidana dari masyarakat. Pemenjaraan terhadap narapidana dilakukan berdasarkan sebuah sistem pemasyarakatan. Berdasarkan ketentuan Pasal 1 angka (2) Undang-undang Nomor 12 Tahun 1995 Tentang Pemasyarakatan, dinyatakan bahwa:

Sistem pemasyarakatan adalah suatu tatanan mengenai arah dan batas serta cara pembinaan warga binaan pemasyarakatan berdasarkan Pancasila yang dilaksanakan secara terpadu antara pembina, yang dibina, dan masyarakat untuk meningkatkan kualitas warga binaan Pemasyarakatan agar menyadari kesalahan memperbaiki diri, dan tidak mengulangi tindak pidana sehingga dapat diterima kembali oleh lingkungan masyarakat, dapat aktif berperan dalam pembangunan, dan dapat hidup secara wajar sebagai warga yang baik dan bertanggungjawab.

Dilihat dari ide 'Pembinaan Narapidana' Dalam redaksi Pasal 2 Undang-Undang Nomor 12 Tahun 1995, tentang Pemasyarakatan menyebutkan bahwa Sistem pemasyarakatan diselenggarakan dalam rangka membentuk Warga Binaan Pemasyarakatan agar menjadi manusia seutuhnya, menyadari kesalahan, memperbaiki diri, dan tidak mengulangi tindak pidana sehingga dapat diterima kembali oleh lingkungan masyarakat, dapat aktif berperan dalam pembangunan, dan dapat hidup secara wajar sebagai warga yang baik dan bertanggung jawab.

Dalam redaksi Pasal 12 tersebut terkesan bertolak pada asumsi bahwa narapidana itu adalah anggota masyarakat yang sakit/rusak, serba kurang/miskin (baik ilmu/harta/pekerjaan/sosialnya) atau tidak mempunyai kemampuan atau tidak memiliki pekerjaan. Menjadi persoalan ketika narapidana tersebut adalah seorang pelajar/mahasiswa, profesional, memiliki pekerjaan dan memiliki keahlian. Ini menunjukkan bahwa telah terjadi perubahan keadaan/kondisi dalam kehidupan masyarakat. Mencari alternatif pidana penjara menjadi suatu keharusan, mengingat juga masalah over kapasitas yang tidak kunjung membaik dari tahun ke tahun. Dibutuhkan alternatif sistem pelaksanaan pidana yang dapat menjadi alternatif baru dalam pelaksanaan pidana yang mengutamakan hak asasi manusia. 
Dilihat dari konteks Indonesia terkait pelaksanaan pidana penjara Pasal 12 UU Nomor 12 tahun 1995 tentang Pemasyarakatan ini, maka narapidana ditempatkan dan dibina berdasarkan karakteristiknya, sehingga tujuan pembinaan dapat tercapai. Dalam pelaksanaannya tidak sesuai dengan isi Pasal 12 sebagaimana yang tercantum dalam UU Nomor 12 Tahun 1995 tersebut, karena jumlah narapidana melebihi kapasitas sehingga penempatan narapidana berdasarkan umur, jenis kejahatan, dan lamanya pidana tidak dapat terwujud. Over kapasitas di Lapas Indonesia terjadi pada hampir semua kantor wilayah (kanwil) lembaga pemasyarakatan. Total narapidana dan tahanan di 33 kanwil pelaksana, terlihat bahwa hanya ada 8 kanwil yang tidak over kapasitas, selebihnya 25 kanwil mengalami over kapasitas (http://smslap.ditjenpas.go.id). Hal tersebut menjadi efek dari banyaknya pengenaan pidana penjara yang diterapkan dalam Kitab Undang Undang Hukum Pidana di Indonesia. Seolah-olah pidana yang dijatuhkan harus pidana penjara. Ide pemasyarakatan berupa rehabilitasi akan sulit terwujud dengan timbulnya over kapasitas di sejumlah lembaga pemasyarakatan. Jumlah narapidana di Lembaga Pemasyarakatan menjadi tidak seimbang dengan jumlah bangunan Lembaga Pemasyarakatannya. Sehingga lambat laun lapas akan menjadi Over Capacity yang mengakibatkan pelaksanaan pidana penjara menjadi kurang efektif. Munculnya kritik menimbulkan respon positif untuk mencari bentukbentuk alternatif pidana penjara agar sesuai dengan ide pelaksanaan pidana yang berkeadilan.

Pelaksanaan pidana penjara yang merupakan bagian dari sistem peradilan pidana perlu segera dilakukan reorientasi mengingat sebagian besar sanksi pidana yang sekarang baik itu dalam Kitab Undang-Undang Hukum Pidana (KUHP) maupun dalam konsep Kitab Undang-Undang Hukum Acara Pidana Baru masih menggunakan bentuk sanksi berupa pidana penjara. Beberapa ketentuan mengenai pidana penjara dan pelaksanaan pidana penjara telah diatur dalam KUHP, KUHAP, Undang-undang, PP, Keputusan Presiden, Keputusan Menteri, dan beberapa perundang-undangan yang terkait dalam pelaksanaan pidana. Dari banyaknya aturan mengenai pelaksanaan pidana tersebut pada kenyataannya belum memiliki keterpaduan terhadap tujuan pemasyarakatan. Masih sangat terlihat kontras bahwa over kapasitas di lembaga pemasyarakatan terjadi di hampir seluruh unit pelaksana lapas di Indonesia.

Lembaga Pemasyarakatan yang merupakan bagian akhir dari sistem pemidanaan dalam tata peradilan pidana adalah integral dari tata peradilan terpadu (integrated criminal justice system). Akan tetapi masalah over kapasitas di hampir seluruh lembaga pemasyarakatan masih persoalan yang tidak kunjung membaik. Sampai saat ini peraturan tentang cuti bersyarat dan pembebasan bersyarat adalah sebagai solusi dari kelebihan kapasitas). Untuk mengurangi kelebihan kapasitas di lapas/rutan, Dirjen Pemasyarakatan melakukan beberapa upaya, salah satunya adalah dengan optimalisasi atau penyederhanaan pemberian Pembebasan Bersyarat, Cuti Menjelang Bebas dan Cuti Bersyarat. Menurut Departemen Hukum dan Hak Asasi Manusia, optimalisasi peningkatan pelayanan pemberian Pembebasan Bersyarat, Cuti Menjelang Bebas dan Cuti Bersyarat merupakan salah satu langkah strategis dalam menangani masalah over kapasitas di Lapas atau Rutan (Berbagai kiat Kemenhukham, 2007).

Upaya tersebut sesuai dengan bunyi Implementation of The Standar Minimum Rules for the Treatment of Prisoners point 11 yang menyatakan bahwa

"Kebijakan untuk menegakkan aturan di dalam lembaga pemasyarakatan tidak akan efektif manakala pada saat yang bersamaan tidak diambil langkah-langkah untuk mengatasi gejala over kapasitas. Usaha-usaha pembinaan terhadap narapidana harus didahului dengan program yang bertujuan untuk mengurangi isi Lapas/Rutan sesuai dengan fasilitas dan sarana yang tersedia". 
Dari pedoman ini dapat disimpulkan bahwa masalah over kapasitas penjara merupakan variabel yang berpengaruh terhadap efektivitas pelaksanaan pembinaan. Oleh karena itu, harus segera dibuat suatu strategi agar over kapasitas tersebut dapat diatasi, sehingga dapat diminimalisir dampak-dampak dari kondisi tersebut.

Lembaga Pemasyarakatan sebagai lembaga pembinaan, posisinya sangat strategis dalam merealisasikan tujuan akhir dari sistem peradilan pidana, yakni rehabilitasi dan resosialisasi pelanggar hukum bahkan sampai pada penanggulangan kejahatan (Supression of Crime). Dapat pula disebut sebagai ujung tombak pelaksana asas pengayoman yang merupakan tempat untuk mencari tujuan dengan jalan pendidikan, rehabilitasi dan reintegrasi. Lembaga Pemasyarakatan merupakan bagian akhir dari sistem pemidanaan dalam tata peradilan pidana yang seyogyanya integral pada tata peradilan terpadu (integrated criminal justice system).

\section{B. Kebijakan Ide Pemasyarakatan dalam Sistem Peradilan Pidana Terpadu di Masa Mendatang}

Usaha pembaharuan hukum di Indonesia yang sudah dimulai sejak proklamasi kemerdekaan tanggal 17 Agustus 1945, melalui Undang-undang Dasar Negara Republik Indonesia Tahun 1945 (UUD NRI 1945) tidak dapat dilepaskan dari landasan dan sekaligus tujuan nasional yang ingin dicapai seperti dirumuskan dalam Pembukaan Undang-undang Dasar Negara Republik Indonesia Tahun 1945, khususnya alinea ke-empat. Ada dua tujuan yang ingin dicapai oleh hukum pidana dan pidana yaitu "perlindungan masyarakat" dan "kesejahteraan masyarakat". Kedua tujuan tersebut sebagai batu landasan ("a cornerstone ${ }^{e c}$ ) dari hukum pidana dan pembaharuan hukum pidana.

Pemasyarakatan dalam sistem peradilan pidana menjadi persoalan dilihat dari sistem pemidanaan, ide pembinaan, masalah over kapasitas yang menjadi sorotan di lembaga pemasyarakatan dan efek buruk dari pidana penjara dimana dalam kesepakatan global melahirkan kritik-kritik terhadap pidana penjara.

Dalam Pasal 1 ke- 1Undang-Undang Republik Indonesia Nomor 12 Tahun 1995 Tentang Pemasyarakatanmenyebutkan bahwa:

"Pemasyarakatan adalah kegiatan untuk melakukan pembinaan Warga Binaan Pemasyarakatan berdasarkan sistem, kelembagaan, dan cara pembinaan yang merupakan bagian akhir dari sistem pemidanaan dalam tata peradilan pidana".

Dalam redaksi Pasal ini jelas menyebutkan bahwa pemasyarakatan merupakan bagian akhir dari sistem pemidanaan dalam tata peradilan pidana

Sedangkan redaksi Pasal 8 Ayat (1) UU Pemasyarakatan ini memberikan penjelasan sebagai berikut:

"Pemasyarakatan yang merupakan bagian akhir dari sistem pemidanaan dalam tata peradilan pidana adalah bagian integral dari tata peradilan terpadu (integrated criminal justice system).

Dengan demikian, pemasyarakatan baik ditinjau dari sistem, kelembagaan, cara pembinaan, dan petugas pemasyarakatan, merupakan bagian yang tak terpisahkan dari satu rangkaian proses penegakan hukum."

Apabila ditelaah kembali, jelas redaksi pasal ini memuat perlunya sistem pemidanaan terpadu dalam sistem peradilan Indonesia. Tidak hanya dalam salah satu sub sistem pemidanaan, namun seyogyanya ide pemasyarakatan ini terimplementasi dalam hukum pidana materiel (KUHP), 
hukum pidana formal (KUHAP), dan hukum pelaksanaan pidana (UU No 12 Tahun 1995). Ide pemasyarakatan demikian berupa ide kemanusiaan (rehabilitasi), ide individualisasi pidana, ide reintegrasi sosial, selektif, limitatif, parsimony dan bersifat sementara. Dalam redaksi pasal ide dalam hukum pelaksanaan pidana yaitu Undang-Undang No 12 Tahun 1995 masih terlaksana sebagian. Masih diharapkan alternatif baru dalam sistem pelaksanaan pidana yang mampu menjawab ide pemasyarakatan yang selama ini belum terimplementasi. Dengan demikian apabila kebijakan yang ingin dikembangkan ialah kebijakan yang diharapkan dapat menjamin penggunaan pidana penjara secara selektif dan limitatif, maka suatu reorientasi dan reevaluasi serta reorganisasi terhadap kebijakan legislatif mutlak diperlukan. Ide baru dalam penggunaan pidana penjara tersebut dapat ditempuh dengan kebijakan-kebijakan baru yang sesuai dengan nilai kemanusiaan dan tentunya tujuan dari lembaga pemasyarakatan.

Over kapasitas di Lapas Indonesia terjadi pada hampir semua kanwil. Total narapidana dan tahanan di 33 kanwil pelaksana, terlihat bahwa hanya ada 8 kanwil yang tidak over kapasitas, selebihnya 25 kanwil mengalami over kapasitas. Hal tersebut menjadi efek dari banyaknya pengenaan pidana penjara yang diterapkan dalam Kitab Undang Undang Hukum Pidana di Indonesia. Seolah-olah pidana yang dijatuhkan harus pidana penjara. Ide pemasyarakatan berupa rehabilitasi akan sulit terwujud dengan timbulnya over kapasitas di sejumlah lembaga pemasyarakatan. Jumlah narapidana di Lembaga Pemasyarakatan menjadi tidak seimbang dengan jumlah bangunan Lembaga Pemasyarakatannya. Sehingga lambat laun lapas akan menjadi Over Capacity yang mengakibatkan pelaksanaan pidana penjara menjadi kurang efektif.

Penjara yang dahulu dikenal handal dalam menangkal kejahatan, sekarang mulai pudar pamornya, justru karena akibat-akibat yang ditimbulkan, seperti mencetak penjahat-penjahat baru yang lebih berbahaya. Selain itu pidana penjara juga menunjukkan kelemahankelemahannya,yaitu menciptakan dehumanisasi maupun desosialisasi, yang dialami mantan narapidana (Muhari 2002). Secara global ada lebih dari sembilan juta tahanandi seluruh dunia dan jumlah itu semakin meningkat. Kenyataannya adalahbahwasemakin banyaktahananakan mengakibatkan overcrowding pada lembaga pemasyarakatan. Hal ini melanggar aturan PBB dan standar lain yang mengharuskan semua tahanan diperlakukan dengan hormat karena martabat yang melekat dan nilai sebagai manusia. Dalam sebuah penelitian yang bertujuan untuk mengeksplorasi efek dari penjara pada narapidana terhadap keluarga, kesehatan dan kesejahteraan dilakukan oleh Dr. Michael Roguski dan Fleur Chauvel menemukan efek buruk dari pidana penjara baik pada keluarga, anak-anak, dan keuangan pada keluarga. ${ }^{2}$ Hal ini menjadi salah satu pertimbangan yang harus dilakukan pada penjatuhan pidana ataupun bagaimana pidana itu dilaksanakan baik dengan pengawasan atau alternatif lain yang memperhatikan pertimbangan demikian, bahwa yang dirugikan tidak hanya terpidana sendiri tetapi juga sampai pada keluarga, anak-anak dan finansial.

\footnotetext{
2 Michael Roguski and Fleur Chauvel, The Effects of Imprisonment on Inmates' and their Families' Health and Wellbeing, (Wellington, 2009), pp vii-x.Impact on family "Both male and female participants commonly cited financial strain, the added strain on their partner due to a loss of parental and childcare support that they had previously provided and breakdown of relationships as impacts of their imprisonment on their families. Women were more likely to focus on child-related impacts." Impact on children "The majority of participants had children under the age of 18 years. The most commonly reported impact of incarceration on children was anxiety and the child's sense of loss and responsibility for their parent's incarceration. These reactions were believed to be compounded by the visiting process, which portrayed their parents negatively and prevented them from showing affection." The impact of imprisonment on children appeared to differ according to the age of the children. The table below summarises commonly identified impacts of parental incarceration on children and how they relate to children within different age groups." Financial stress "Significant financial pressures were commonly experienced by family members due to the imprisonment of their partner or family member. This commonly required the reallocation of finances, which potentially or actually affected health and wellbeing"
} 
Prinsip semakin sedikit jumlah penghuni maka semakin sedikit anggaran yang akan dihabiskan menjadi penting untuk diperhatikan. Pada tingkat ekologi, kepadatan menjadi terkait dengan biaya ekonomi dan manfaat, yang efisien atau tidak efisien dalam pemberian layanan dan persyaratan kustodian berkaitan dengan pemantauan dan pengendalian populasi narapidana. Artinya, kepadatan dapat mempengaruhi sebuah kemampuan lembaga untuk mengontrol perilaku dan menjaga kesehatan. Di tingkat individu, kepadatan bisa memiliki efek yang sangat berbeda pada stres, dan akibatnya terhadap perilaku dan kesehatan. Singkatnya, kepadatan memiliki efek yang berbeda pada lembaga dan individu, dan efek kepadatan pada lembaga dapat memodifikasi efek pada individu.

Prinsip reintegrasi sosial narapidana membantu untuk mencegah terulangnya tindak pelanggaran harus berada tepat di pusat strategi dan kebijakan manajemen penjara. Berbagai kaidah yang termasuk dalam instrumen internasional didasarkan pada pemahaman ini. Dimana pihak berwenang lebih menitikberatkan pada pidana penjara dan pencegahan menjadi tujuan pidana dari pada rehabilitasi individu. Ada kemungkinan berkurangnya layanan dan fasilitas yang diperlukan dalam mendukung reintegrasi sosial yang efektif. Dalam prakteknya, sebagian besar anggaran sistem penjara digunakan untuk memberikan keamanan, keselamatan dan ketertiban, dan sejumlah kecil dananya akan diinvestasikan dalam seminar, pelatihan keterampilan, fasilitas pendidikan, olahraga dan rekreasi di penjara.

Menjadikeyakinan yang keliru bahwa keamanan dapat dicapai dengan tindakan pembatasan dan penerapan disiplin. Seharusnya dilakukan dengan memperbaiki lingkungan penjara, memberikan pelatihan konstruktif dan pekerjaan bagi para narapidana, pengobatan untuk ketergantungan obat dan/atau gangguan kesehatan mental, pendidikan, rekreasi dan rezim penjara yang meningkatkan potensi tahanan untuk hidup taat pada hukum saat dibebaskan. Kekurangan tersebut akan semakin parah ketika penghuni penjara begitu padat.

Adanya kecenderungan penjatuhan pidana penjara dilihat dari total 210.513 narapidana, terdapat 142.292 orang atau sekitar $68 \%$ yang menjalani pidana penjara di bawah 1 tahun, sedangkan di atas 1 tahun hanya sebagian kecil saja yaitu $32 \%$. Kecenderungan penjatuhan ini merupakan suatu masalah yang sepatutnya ditinjau kembali melalui politik kriminal (http://smslap.ditjenpas.go.id, diakses tanggal 25 Agustus 2016). Dalam kebijakan hukum di Indonesia memiliki program pidana bersyarat yang merupakan salah satu program dalam pelaksanaan pidana dalam rangka mengurangi over kapasitas di lembaga pemasyarakatan, namun tetap saja tidak cukup untuk menjawab masalah over kapasitas lapas di indonesia. Untuk mengurangi over kapasitas, RUU KUHP Indonesia Tahun $2015^{3}$, telah menyebutkan

\footnotetext{
${ }^{3}$ Terdapat dalam buku ke satu 'ketentuan umum' RUU KUHP 2015, dalam Bab III Pemidanaan, Pidana, Dan Tindakan. Diperoleh penulis langsung dari Barda Nawawi Arief sebagai editor hasil rapat tim perumus RUU KUHP DI BPSDM Tgl. 1 Sd 6 Desember 2014, dengan memberikan usulan perubahan tanggal 14 Februari 2015, perubahan dalam redaksi Pasal 73 tersebut yaitu:

a. $\quad$ ayat (1) Dalam hal hakim menjatuhkan pidana penjara 1 (satu) tahun, diubah menjadi "penjara 1 (satu) tahun atau kurang dari 1 (satu) tahun, ...."

b. ayat (2) diusulkan berubah menjadi : "Pelaksanaan pidana penjara cicilan/ angsuran menurut ayat (1) di atas hanya dapat diberikan apabila hakim mempertimbangkan adanya kondisi yang sangat gawat atau menimbulkan akibat lain yg sangat mengkhawatirkan apabila terdakwa menjalani pidananya secara berturutturut"

c. ayat (3) : Ketentuan mengenai pelaksanaan pidana cicilan/ angsuran sebagaimana dimaksud pada ayat (1) dapat dilaksanakan paling lama 2 (dua) hari dalam 1 (satu) minggu atau 10 (sepuluh) hari dalam sebulan dengan ketentuan "jumlah/lama cicilan/ angsuran tidak melebihi 3 (tiga) tahun", diubah menjadi : "lamanya cicilan/angsuran tidak melebihi 3 (tiga) tahun”.
} 
pertimbangkan Pasal 55 dan Pasal 56, pidana penjara sejauh mungkin tidak dijatuhkan, jika dijumpai keadaan-keadaan sebagai berikut:

a. Terdakwa berusia di bawah 18 (delapan belas) tahun atau di atas 70 (tujuh puluh) tahun;

b. Terdakwa baru pertama kali melakukan tindak pidana;

c. Kerugian dan penderitaan korban tidak terlalu besar;

d. Terdakwa telah membayar ganti kerugian kepada korban;

e. Terdakwa tidak mengetahui bahwa tindak pidana yang dilakukan akan menimbulkan kerugian yang besar;

f. Tindak pidana terjadi karena hasutan yang sangat kuat dari orang lain;

g. Korban tindak pidana mendorong terjadinya tindak pidana tersebut;

h. Tindak pidana tersebut merupakan akibat dari suatu keadaan yang tidak mungkin terulang lagi;

i. Kepribadian dan perilaku terdakwa meyakinkan bahwa ia tidak akan melakukan tindak pidana yang lain;

j. Pidana penjara akan menimbulkan penderitaan yang besar bagi terdakwa atau keluarganya;

k. Pembinaan yang bersifat non-institusional diperkirakan akan cukup berhasil untuk diri terdakwa;

1. Penjatuhan pidana yang lebih ringan tidak akan mengurangi sifat beratnya tindak pidana yang dilakukan terdakwa;

m. Tindak pidana terjadi di kalangan keluarga; atau

n. Terjadi karena kealpaan.

Mengikuti redaksi pasal tersebut, maka dalam pelaksanaan/penjatuhan pidana penjara seyogyanya mengandung ide dasar yakni:

1. Ide pidana penjara sebagai obat terakhir (last resort);

2. Ide/prinsip penghematan (the principle of parsimony) dan prinsip menahan diri (principle of restraint) dalam menggunakan pidana penjara.

3. Ide mengurangi akibat negatif dari pidana penjara;

4. Ide pidana penjara sebaiknya jangan dikenakan kepada pelanggar-pelanggar ringan (petty offenders);

5. Ide mengurangi "overcrowding" yang diakibatkan "penjara" sebagai sanksi primadona.

\section{KESIMPULAN DAN SARAN}

\section{A. KESIMPULAN}

1. Problematika over kapasitas dalam lembaga pemasyarakatan menjadi implikasi sistem pemidanaan yang memprimadonakan pidana penjara pada hukum materiel, sehingga ideide pemasyarakatan dalam sistem pemidanaan terpadu antara lain Ide kemanusiaan, penghematan, rehabilitasi, selektif dan limitative tidak dapat berjalan sesuai dengan tujuan pemidanaan.

2. Sistem pemidanaan/ sistem peradilan pidana terpadu belum terintegrasi ide-ide pemasyarakatan sebagai bagian akhir dari sistem pemidanaan, baik dalam hukum pidana materiil, hukum pidana formal dan hukum pelaksanaan pidana. Masalah over kapasitas di seluruh lapas Indonesia terjadi pada hampir semua kanwil. Hal demikian menunjukkan adanya kecenderungan penjatuhan pidana penjara.

\section{B. SARAN}

1. Perlu adanya perubahan pada substansi hukum materiel agar pelaksanaan pidana penjara berupa ide kemanusiaan, penghematan, rehabilitasi dan ide selektif dapat diwujudkan 
dalam sistem pemidanaan terpadu sehingga penghormatan hak asasi manusia terlihat dalam pelaksanaan pidana di Indonesia.

2. Pelaksanaan pidana penjara yang merupakan bagian dari sistem peradilan pidana perlu dilakukan reorientasi yaitu dengan menerapkan alternatif pidana penjara baru yang sesuai dengan ide-ide pemasyarakatan dan tujuan pemidanaan.

\section{REFERENSI}

Berbagai kiat Menhukham mengatasi mebludaknya kapasitas LP (2007, 19 Juli). Diunduh dari http://www.hukumonline.com/berita/baca/hol17198/berbagai-kiat-menhukham-mengatasimembludaknya-kapasitas-lp.

Kitab Undang-Undang Hukum Acara Pidana.

Kitab Undang-Undang Hukum Pidana.

Mahmud Marzuki, Peter.(2010). Penelitian hukum. Jakarta: Kencana.

Menhumkam beberkan persoalan di lapas. (2016, 11 April). Diunduh dari http:// www.antaranews.com/berita/554673/menkumham-beberkan-persoalan-di-lapas.

Nawawi Arief, Barda. (2010).Kebijakan legislatif dalam penanggulangan kejahatan dengan pidana penjara. Yogyakarta: Genta Publishing. , Arief Barda. (2013). Kapita Selekta Hukum Pidana. Bandung: Citra Aditya Bakti.

Roguski, Michael and Fleur Chauvel. (2009). The Effects of Imprisonment on Inmates' and their Families' Health and Wellbeing. Wellington.

RUU Kitab Undang-Undang Hukum Pidana Tahun 2015.

Santoso, Muhari Agus.(2002). Paradigma Baru HukumPidana. Malang: Averroes Press.

Slamet Kurnia, Titon. dkk.(2013). Pendidikan hukum, ilmu hukum dan penelitian hukum di Indonesia:Sebuah Reorientasi. Yogyakarta: Pustaka Pelajar.

Soemitro, Rony Hanitiyo. (1994). Metode penelitian hukum dan juri metri. Jakarta: Ghalia Indonesia.

Sudarto.(1981). Kapita selekta hukum pidana. Bandung: Alumni.

Suhariyono, A. R. (2012). Pembaruan pidana denda di Indonesia (Pidana denda sebagai sanksi alternatif). Jakarta: Papas Sinar Sinanti.

Undang-undang Nomor 12 tahun 1995 tentang Pemasyarakatan.

http://www.tempo.co/read/news.

http://smslap.ditjenpas.go.id. 